\title{
Diabetes mellitus and apoptosis: inflammatory cells
}

\author{
Aidan Ryan · Madeline Murphy • Catherine Godson • \\ Fionnuala B. Hickey
}

Published online: 10 April 2009

(C) Springer Science+Business Media, LLC 2009

\begin{abstract}
Since the early observation that similarities between thyroiditis and insulitis existed, the important role played by inflammation in the development of diabetes has been appreciated. More recently, experiments have shown that inflammation also plays a prominent role in the development of target organ damage arising as complications, with both elements of the innate and the adaptive immune system being involved, and that cytokines contributing to local tissue damage may arise from both infiltrating and resident cells. This review will discuss the experimental evidence that shows that inflammatory cellmediated apoptosis contributes to target organ damage, from beta cell destruction to both micro- and macro-vascular disease complications, and also how alterations in leukocyte turnover affects immune function.
\end{abstract}

Keywords Diabetes - Microvascular complications · Macrovascular complications · Apoptosis · Inflammation

$\begin{array}{ll}\text { Abbreviations } \\ \text { ACAT } & \text { Acyl Co-A: cholesterol acyltransferase } \\ \text { AGE } & \text { Advanced glycation end products } \\ \text { AIM } & \text { Apoptosis inhibitor expressed by macrophages } \\ \text { APC } & \text { Antigen presenting cells } \\ \text { APO } \varepsilon & \text { Apolipoprotein E } \\ \text { BMP } & \text { Bone morphogenetic protein } \\ \text { CB2 } & \text { Canabinoid 2 } \\ \text { CCL-2 } & \text { Chemokine ligand } 2 \\ \text { CCR } & \text { Chemokine receptor }\end{array}$

A. Ryan · M. Murphy · C. Godson ( $₫)$ F. B. Hickey UCD Diabetes Research Centre, UCD Conway Institute, School of Medicine and Medical Science, University College Dublin, Dublin, Ireland

e-mail: catherine.godson@ucd.ie

$\begin{array}{ll}\text { CKD } & \text { Chronic kidney disease } \\ \text { Cox-2 } & \text { Cyclooxygenase-2 } \\ \text { CTGF } & \text { Connective tissue growth factor } \\ \text { CTL } & \text { Cytotoxic T lymphocyte } \\ \text { CVD } & \text { Cardiovascular disease } \\ \text { DC } & \text { Dendritic cells } \\ \text { DN } & \text { Diabetic nephropathy } \\ \text { DR } & \text { Diabetic retinopathy } \\ \text { EMT } & \text { Epithelial-mesenchymal transformation } \\ \text { ER } & \text { Endoplasmic reticulum } \\ \text { ESRD } & \text { End-stage renal failure } \\ \text { FasL } & \text { Fas ligand } \\ \text { FC } & \text { Free cholesterol } \\ \text { FLIP } & \text { FLICE-like inhibitory protein } \\ \text { FoxO } & \text { Forkhead transcription factor } \\ \text { HGF } & \text { Hepatocyte growth factor } \\ \text { IAP } & \text { Inhibitor of apoptosis } \\ \text { IHG-1 } & \text { Induced in high glucose-1 } \\ \text { IL } & \text { Interleukin } \\ \text { IL-1Ra } & \text { IL-1 receptor antagonist } \\ \text { iNOS } & \text { Inducible NO synthase } \\ \text { IRAK } & \text { Interleukin-1 receptor-associated kinase } \\ \text { LDL } & \text { Low-density lipoprotein } \\ \text { LOX-1 } & \text { LDL receptor-1 } \\ \text { Lp-PLA2 } & \text { Lipoprotein-associated phospholipase A2 } \\ \text { LPS } & \text { Lipopolysaccharide } \\ \text { M-CSF } & \text { Macrophage colony-stimulating factor } \\ \text { MCP-1 } & \text { Monocyte chemotactic protein-1 } \\ \text { MIF } & \text { Migration inhibitory factor } \\ \text { NO } & \text { Nitric oxide } \\ \text { NOD } & \text { Nonobese diabetic } \\ \text { ox-LDL } & \text { Oxidised low-density lipoprotein } \\ \text { PARP } & \text { Poly (ADP-ribose) polymerase } \\ \text { PLC } & \text { Phospholipase C } \\ \text { PPAR } & \text { Peroxisome proliferator-activated receptor } \\ & \\ & \end{array}$




$\begin{array}{ll}\text { RAAS } & \text { Renin-angiotensin-aldosterone } \\ \text { RAGE } & \text { Receptor for advanced glycation end products } \\ \text { RIP } & \text { Rat insulin promoter } \\ \text { ROS } & \text { Reactive oxygen species } \\ \text { SR-A } & \text { Macrophage scavenger receptor A } \\ \text { STZ } & \text { Streptozotocin } \\ \text { T1DM } & \text { Type 1 diabetes mellitus } \\ \text { T2DM } & \text { Type } 2 \text { diabetes mellitus } \\ \text { TCR } & \text { T cell receptor } \\ \text { TIF } & \text { Tubulointerstitial fibrosis } \\ \text { TIMP } & \text { Tissue inhibitors of metalloproteinase } \\ \text { TLR } & \text { Toll-like receptor } \\ \text { TNF } & \text { Tumour necrosis factor } \\ \text { TRAIL } & \text { TNF Related Apoptosis Inducing Ligand } \\ \text { Treg } & \text { Regulatory T cells } \\ \text { UPR } & \text { Unfolded protein response } \\ \text { UPS } & \text { Ubiquitin-proteasome system } \\ \text { VCAM-1 } & \text { Vascular cell adhesion molecule-1 } \\ \text { VLA-4 } & \text { Very late-acting antigen-4 }\end{array}$

\section{Introduction}

Diabetes mellitus is a complex syndrome characterised by absolute insulin deficiency or resistance leading to hyperglycaemia, as a result of inadequate transport of glucose from the vasculature into fat and muscle. Diabetic patients exhibit altered glucose, fat and protein metabolism. These metabolic dysfunctions alter the cellular microenvironment in many different tissue types, resulting in a myriad of long-term effects that are collectively referred to as "diabetic complications" including microvascular complications such as diabetic nephropathy (DN), neuropathy and retinopathy along with macrovascular complications such as accelerated atherosclerosis causing ischaemic heart and cerebrovascular disease.

Two major forms of diabetes occur-type 1 diabetes mellitus (T1DM) and type 2 diabetes mellitus (T2DM). T1DM occurs when the insulin-producing $\beta$-cells in the pancreas are destroyed, typically by an autoimmune, $\mathrm{T}$ cell-mediated mechanism, resulting in the production of insufficient amounts of insulin [1]. T2DM is caused by a resistance to insulin combined with a failure to produce sufficient insulin. T2DM is commonly linked to obesity, which can cause insulin resistance [2, 3]. Despite the different pathogenic mechanisms of T1DM and T2DM, they share common symptoms including glucose intolerance, hyperglycaemia, hyperlipidaemia and similar complications. A pivotal role for reactive oxygen species (ROS) has been proposed in both the development of insulin resistance and in the pathogenesis of complications of both the micro- and macro-vasculature [4-6].
An inflammatory cell is by definition, any cell that participates in an inflammatory response and as such can be resident or infiltrating cells. Classical inflammatory cells include macrophages, lymphocytes, dendritic cells (DC), neutrophils and eosinophils. Inflammation plays an important role in many aspects of diabetes and related complications. Systemic levels of pro-inflammatory cytokines including tumour necrosis factor (TNF)- $\alpha$, interleukin (IL)- $1 \beta$ and IL-6 are elevated in patients with both type 1 and type 2 diabetes. Increases in these cytokines can directly promote insulin resistance [7-9]. There is also a growing appreciation of the role of inflammation in diabetic complications [10].

\section{$\beta$-Cell apoptosis}

The pancreatic $\beta$-cells of the islets of Langerhans are the sole source of insulin. Apoptotic destruction of the insulinproducing pancreatic $\beta$-cells is involved in the aetiology of both type 1 and type 2 diabetes. The onset of T1DM is relatively sudden and by the time of diagnosis $\beta$-cell mass is reduced by $70-80 \%$. Apoptotic signals come from high concentrations of inflammatory cytokines or $\mathrm{T}$ cells in the islet microenvironment [11]. The pathogenesis of T2DM is more variable, comprising different degrees of $\beta$-cell loss relative to varying degrees of insulin resistance. A significant reduction in $\beta$-cell mass and a threefold increase in $\beta$-cell apoptosis is seen in patients with T2DM [12]. In T2DM, inflammatory cytokines are produced in insulinsensitive tissues leading to elevated circulating levels of IL-6 and TNF- $\alpha$ [13]. In addition, glucose has been reported to induce $\beta$-cell apoptosis via the induction of autocrine production of IL- $1 \beta$ by $\beta$-cells, which leads to increased expression of Fas and apoptosis [14].

\section{Type 1 diabetes}

Much of our understanding of the role of inflammatory cells in diabetes has been generated from the use of animal models. The nonobese diabetic (NOD) mouse is a spontaneous murine model that closely mimics T1DM. In this context T1DM is attributable to the autoimmune destruction of the pancreatic $\beta$-cells [15]. A number of defects in the immune system of the NOD mouse have been reported, suggesting that the predisposition of NOD mice to T1DM is due to abnormalities in peripheral tolerance mechanisms $[15,16]$. The nature of the immunological effectors that induce $\beta$-cell apoptosis in T1DM is still debated. Autoreactive T-cells and an inflammatory response in which TNF- $\alpha$, IL- $1 \beta$, IFN- $\gamma$, perforin, granzyme $\mathrm{B}$, Fas ligand (FasL), nitric oxide (NO), or a combination of all of the above, have been implicated [17-19]. It is most likely that these 
molecules act in synergy to induce caspase-3-dependent apoptotic signalling cascades $[19,20]$.

Detection of T1DM in NOD mice is preceded by islet inflammation (insulitis). This occurs as a result of the infiltration of pancreatic islets with macrophages, DC, $\mathrm{B}$ cells, $\mathrm{CD}^{+}{ }^{+}$and $\mathrm{CD}^{+}{ }^{+} \mathrm{T}$ cells. B cells account for $60-70 \%$ of the intra-islet immune cells [21]. The process of recruitment of $\mathrm{T}$ cells to pancreatic islets is not fully understood, however, it most likely involves the production of chemokines by local antigen presenting cells (APC). Prolonged insulitis leads to the preferential amplification of autoreactive $\mathrm{CD} 8^{+} \mathrm{T}$ cells with high affinity $\mathrm{T}$ cell receptors (TCR) [22]. These high affinity pre-cytotoxic $\mathrm{T}$ lymphocytes (CTLs) become differentiated into CTLs via TCR recognition of target peptide-MHC I complexes on local APC. Co-stimulatory pathways involving CD28-B7 are essential in this process [23]. $\mathrm{CD}^{+}$CTLs initiate the immune response via the production of perforin. Perforin is a key component of CTLs. NOD mice lacking the perforin gene develop insulitis but significantly delayed and reduced diabetes [24]. This supports a role for perforin, but also highlights the fact that other mechanisms are involved in $\beta$-cell destruction. This may be effected by $\mathrm{CD}^{+}{ }^{+} \mathrm{T}$ cells via Fas/FasL interaction and production of the inflammatory cytokines IFN- $\gamma$ and TNF- $\alpha$ [25]. Binding of TNF- $\alpha$ and IFN- $\gamma$ to their cognate receptors on $\beta$-cells induces apoptosis through caspase cleavage or NO production via regulation of inducible NO synthase (iNOS) [26, 27]. IFN- $\gamma$ also enhances IL- $1 \beta$ production by APC which is also toxic to $\beta$-cells [28]. Proinflammatory cytokines, TNF- $\alpha$, IFN- $\gamma$, and IL-1 $\beta$, can also upregulate Fas expression on $\beta$-cells, facilitating cell recognition, and also stimulate $\mathrm{NO}$ and ROS production, exacerbating cell death [29-32] (see Fig. 1).

\section{Type 2 diabetes}

Similar to T1DM, T2DM is also characterised by progressive loss of $\beta$-cells. However, while the mechanism of $\beta$-cell apoptosis in T1DM is dependent on the infiltration of inflammatory cells, multiple pathways have been proposed to be involved in the destruction of $\beta$-cells in T2DM. These mechanisms include increased circulating cell nutrients [33, 34], endoplasmic reticulum (ER) stress [35], signalling factors from adipocytes [36] and more recently, infiltration of immune cells. The proinflammatory cytokine IL- $1 \beta$ is one of the unifying mechanisms of $\beta$-cell death in both T1DM and T2DM. Increased expression of IL- $1 \beta$ in pancreatic $\beta$-cells from patients with T2DM has been reported by a number of groups $[14,37]$. Further to this, a clinical trial was conducted using the natural soluble IL-1 receptor antagonist (IL-1Ra) in T2DM [38] and improved glycaemic control was observed in IL-1Ra-treated versus placebo-treated patients, based on glycated haemoglobin

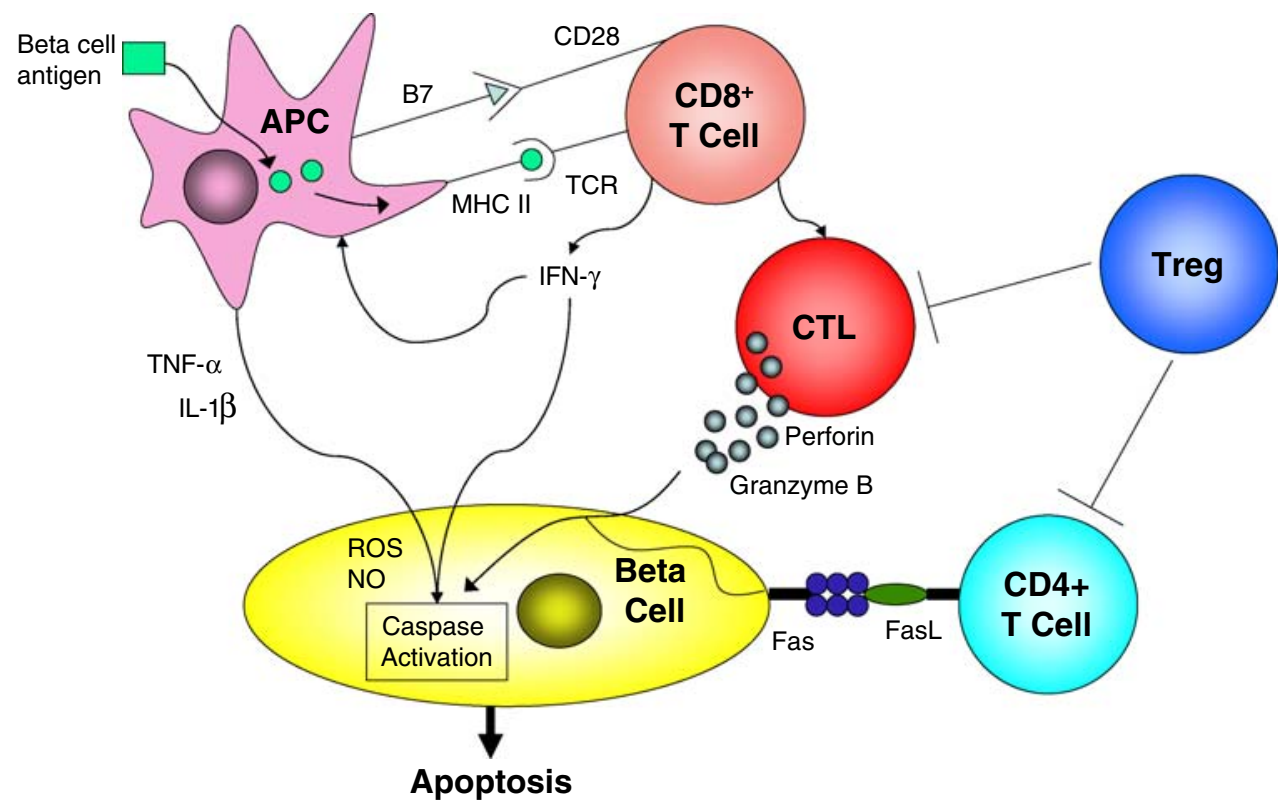

Fig. $1 \beta$-cell apoptosis in T1DM: Beta cell antigen is taken up by antigen presenting cells $(A P C)$. This antigen is processed into antigenic fragments and bound to MHC II. The antigen-MHC II complex is externalised and recognised by $\mathrm{T}$ cell receptors $(T C R)$. $\mathrm{T}$ cells are activated by antigen recognition and costimulation by secondary signals-CD28-B7. The activated cytotoxic T lymphocyte
(CTL) produces IFN- $\gamma$, which can subsequently stimulate the APC to produce further inflammatory cytokines IL- $1 \beta$ and TNF- $\alpha$, and releases cytoxic molecules including granzyme B or perforin. IL-1 $\beta$ upregulates Fas expression on beta cells, thereby sensitising them to T cell-mediated apoptosis via Fas/FasL. In contrast, CD4+CD25+ Foxp3+ regulatory $\mathrm{T}$ cells suppress effector $\mathrm{T}$ cells 
levels. However, this study was limited by its short duration of only 13 weeks. Further studies evaluating the longterm use of IL-1Ra will determine if IL-1 antagonism represents a potential therapy in the preservation of $\beta$-cells in T2DM.

Along with increased $\beta$-cell apoptosis, pancreatic islets from T2DM patients also present with amyloid deposits and fibrosis $[39,40]$. These are hallmarks of an unresolved inflammatory response. Given that pancreatic $\beta$-cell mass is now known to be reduced in T2DM [12], the immune system is most likely associated with the removal of these apoptotic cells. However, recent evidence indicates that islet macrophage infiltration occurs in human and animal models of T2DM before the onset of islet cell death [41, 42].

B cells

B cells are the predominant immune cell found in pancreatic islets. The high prevalence of intra-islet B cells is primarily due to their involvement in the priming and epitope spreading of $\mathrm{CD}^{+} \mathrm{T}$ cells [43]. In addition to this, pancreatic islet $\mathrm{B}$ cells have recently been found to promote the survival of activated $\mathrm{CD}^{+} \mathrm{T}$ cells at the transition stage [21]. In this study RIP-TNF $\alpha$-transgenic NOD mice (NOD mice in which constitutive expression of TNF- $\alpha$ is achieved exclusively in islets as it is under the control of the rat insulin promoter [RIP]) were crossed with B cell-deficient NOD mice. B cell deficiency significantly delayed the development of diabetes but did not impair $\mathrm{CD}^{+}{ }^{+}$and $\mathrm{CD} 8^{+}$T-cell activation. Reintroduction of $B$ cells incapable of secreting immunoglobulins restored diabetes development. Suppression of disease was in fact due to apoptosis of intra-islet cytotoxic $\mathrm{T}$ cells at the transition stage. B cell deficient NOD mice did eventually develop diabetes suggesting that the requirement for B cells can be compensated by some other cell type.

\section{Treatment of diabetes}

The main treatment for hyperglycaemia in patients with T1DM is insulin replacement, typically by injection of the recombinant hormone. More recently, pancreatic transplant has been demonstrated to prolong and improve the quality of life, however, the procedure requires major surgery and long-term immunosuppression [44]. The transplant of pancreatic islets has been reported as an alternative treatment that would accomplish insulin independence and completely correct the DM but without major surgery. However, $<10 \%$ of patients remain insulin independent 5 years after islet transplantation due to allogeneic immune responses [45]. This low success rate occurs even when transplantation is accompanied by chronic immunosuppression which may be detrimental to the patient as it increases the risk of fatal opportunistic infections as well the adverse effects of intrinsic $\beta$-cell toxicity arising from such medication [46].

Several methods have been employed in order to prevent the destruction of the transplanted $\beta$-cells. In order to maintain long-term graft function both alloimmune and autoimmune barriers must be overcome. As such, induction of tolerance is one of the main objectives in islet transplantation. Initial studies examined the potential of gene therapy in the treatment of T1DM, whereby pancreatic islets were transduced, before transplantation, with factors such as death ligands in order to eliminate autoreactive $\mathrm{T}$ cells by apoptosis. To date, various death ligands of the TNF family including FasL, TNF- $\alpha$ and TNF Related Apoptosis Inducing Ligand (TRAIL) have been tested for their ability to protect transplanted islets. In transplantation models, artificial expression of FasL on the islet transplant resulted in accelerated rejection of the graft by neutrophils $[47,48]$. This is thought to be due to stimulation of IL- $1 \beta$ production by over-expressed FasL [49]. Similarly, islets transplanted from RIP-TNF- $\alpha$ NOD donors were rejected in diabetic NOD mice [50]. To date, no studies have investigated the effect of artificial TRAIL expression on islet transplantation. However, studies in two animal models of T1DM suggest that TRAIL expression may promote the downregulation of autoimmune inflammatory responses. Lamhamedi-Cherradi et al. [51] reported that blockade of TRAIL via injection of a soluble TRAIL receptor into NOD mice resulted in increased inflammation in pancreatic islets and earlier onset of diabetes. Similarly, TRAIL-knockout mice displayed enhanced islet inflammation and earlier onset of diabetes following low doses of the $\beta$-cell toxin streptozotocin (STZ) [51]. Although most normal primary islet cells express all four TRAIL receptors [52], primary islets isolated from donors are resistant to TRAIL-induced apoptosis [53]. This may be due to the ratio of TRAIL death to decoy receptors on these cells. In fact, high levels of expression of decoy receptors have recently been demonstrated in human islets [54]. These results suggest that contrary to what was observed with FasL or TNF- $\alpha$, TRAIL gene delivery into pancreatic islets may be therapeutically beneficial.

The above studies aimed to prevent the destruction of transplanted islets by inducing apoptosis in graft-specific activated $\mathrm{T}$ cells. Other strategies have been employed that aim to induce peripheral tolerance via induction and expansion of regulatory $\mathrm{T}$ cells (Tregs). Initial studies aimed to divert the immune response by expressing IL-10, which has anti-inflammatory properties including the inhibition of proinflammatory cytokines (e.g. IL-2, IL-12, IFN- $\gamma$ ) [55]. In addition, production and action of IL-10 had been suggested to be deficient in both human patients 
and experimental models of T1DM [56, 57]. However, adenovirus-induced expression of IL-10 in islet grafts failed to prevent $\beta$-cell apoptosis and the recurrence of diabetes [58]. It has been reported that injection of $\mathrm{CD} 4{ }^{+} \mathrm{CD} 25^{+} \mathrm{CD} 62 \mathrm{~L}^{+}$Tregs that have been expanded with antigen-pulsed DC and IL-2 into NOD mice blocked the development of diabetes in prediabetic mice. In addition, long-lasting reversal of hyperglycaemia was observed in $50 \%$ of mice in which overt diabetes had developed [59]. The main challenge is in obtaining sufficient numbers of alloantigen-specific Tregs [60, 61].

\section{Diabetic complications}

Due to the increasing prevalence of diabetes, especially T2DM, complications secondary to diabetes are currently a substantial public health issue, in terms of disease burden and health expenditure [62]. Diabetic complications frequently reflect the impact of chronic hyperglycaemia, metabolic dysregulation, endothelial dysfunction and there is a growing body of evidence suggesting that inflammation, more specifically proinflammatory cytokines, play a key role in the development of diabetic complications including (DN) [63], retinopathy [64] and neuropathy [65] and that diabetic complications may reflect impaired resolution of inflammatory processes [66].

\section{Impaired immune function}

Patients with diabetes are considered to be at increased risk of bacterial, viral and fungal infections, and often experience more prolonged and serious infections [67, 68]. For example, hyperglycaemia is a risk factor for poor outcomes in patients admitted to ICU with sepsis [69]. Studies of the phagocytic and antimicrobial activities of neutrophils in diabetic patients have shown decreased chemotactic activity, decreased bactericidal activity, decreased lysosomal enzyme release, reduced ROS release, and impairment of phagocytosis [70]. It should be emphasised that the patients involved in these studies mainly had poor glycaemic control. The mechanisms underlying this have been investigated using both cell culture models and human ex-vivo studies, and involve impairment of the normal inflammatory response combined with hyperglycaemia-mediated alteration in lipid and protein function, leading to advanced glycation end products (AGEs) and methglyxol formation. Experiments in patients with both type 1 and type 2 diabetes have shown that increased inflammatory cytokine release may also play a role in this [71-73].

A high occurrence of apoptotic lymphocytes has been shown in diabetic patients, resulting in reduced numbers of circulating lymphocytes in these patients [74]. Increased apoptosis of lymphocytes in patients with diabetes may explain the impaired immune function in poorly controlled diabetic patients. In particular, neutrophil apoptosis is an integral component of inflammation and its resolution. Neutrophils from diabetic patients demonstrate defects in lipopolysaccharide (LPS)-mediated apoptosis. LPS inhibits apoptosis in normal neutrophils but fails to do so in diabetic neutrophils potentially compromising effective host defence [75].

Macrovascular complications-cardiovascular disease and macrophage apoptosis

The risk of cardiovascular disease (CVD) is increased two to threefold in patients with diabetes with cardiovascular complications of diabetes including atherosclerosis, heart failure, diastolic dysfunction and cardiomyopathy, and arise as a result of increased dyslipidaemia, elevated levels of inflammatory mediators, coagulation factors, hypertension, hyperglycaemia and vascular dysfunction associated with insulin resistance [76, 77]. In addition, macrovascular disease has a more severe course in diabetics than in nondiabetics, with greater prevalence of multi-vessel coronary artery disease and more diffuse elongated atheromatous plaques in affected blood vessels [78]. Previously it was thought that this disease process was a manifestation of lipid accumulation in the arterial intima, in combination with the effects of cardiovascular risk factors such as hypertension, smoking and diabetes, however, recently there has been an appreciation of the importance of the role of inflammation.

Studies from both animal models and humans have shown that from its earliest stages of development, atherosclerosis contains a significant inflammatory component, that contributes to its progression and to the development of complications [79]. Although the evidence implicating inflammation in atherosclerosis and diabetes is wide ranging, a specific mechanism has not been identified to explain precisely why patients with diabetes are at increased risk of inflammation and atherosclerosis. It should be borne in mind that due to the chronic nature of complication development, many of the mechanisms implicated in atherosclerosis in diabetics are also seen in non-diabetics [76, 77].

In the initial stage of atheroma formation, monocyte derived macrophages play a crucial role by internalising oxidised low-density lipoprotein (ox-LDL) through scavenger receptors, leading to the formation of what are termed foam cells [80]. During this process not only is the lipid altered but also the macrophage, which becomes trapped in the intima, contributing to lesion development, lipid accumulation and to vessel wall inflammation. 
Apoptosis occurs in all cells of the atherosclerotic plaque, the significance of which depends on plaque stage, localisation and the cell type involved [81]. However, there is some experimental evidence to show that macrophages are more susceptible to apoptosis from a variety of stimuli, than vascular smooth muscle cells and endothelial cells [82].

Macrophage apoptosis occurs during all stages of atherosclerosis, and with improvements in the development of mouse models it has been possible to explore the functional consequences at each stage of the disease process. In relatively early lesions macrophage apoptosis limits lesion cellularity and plaque progression whereas in advanced lesions, macrophages promote the development of a necrotic core, increasing plaque instability [83]. Bone marrow transplantation studies with mice deficient in apoptosis inhibitor expressed by macrophages (AIM) or Bax (a propapoptotic protein), suggest that enhanced macrophage apoptosis in developing foam cells limits lesion inflammation and progression [84, 85]. Macrophages are a potent source of proinflammatory cytokines and proteases, which may create the environment in which a previously stable plaque ruptures leading to an acute thrombotic event $[86,87]$. A postmortem study of sudden cardiac death comparing morphologic findings of coronary atherosclerotic plaques in diabetics and non-diabetics has shown a larger necrotic core, increased inflammatory cell infiltrate, increased expression of the receptor for AGEs (RAGE) and increased macrophage apoptosis [88]. Increased apoptosis of insulin resistant macrophages and impaired phagocytic clearance of apoptotic cells by macrophages in atherosclerotic lesions may result in enhanced post-apoptotic necrosis, larger lipid-rich cores, increasing both inflammation and plaque instablility.

Macrophage death in atherosclerotic plaques is a multifactorial process depending on disease stage. Broadly speaking, the factors that influence this include: (1) apoptotic activation; (2) apoptotic inhibition; (3) endoplasmic reticulum activation; (4) macrophage receptors; (5) signalling pathway activation; (6) lipid metabolism; (7) impairment of efferocytosis (see Fig. 2 for summary overview of factors involved in macrophage apoptosis).

Apoptosis involves two main intracellular pathways with significant cross-talk between each [89]. Ligand binding to death receptors such as Fas and TRAIL has been termed the "extrinsic pathway" [90]. The "intrinsic pathway" centers around the mitochondria [91], with the balance between pro- and anti-apoptotic Bcl-2 family members controlling the release of proapoptotic factors such as cytochrome $\mathrm{C}$ from the mitochondrial intermembrane space. Cytosolic cytochrome $\mathrm{c}$ then promotes caspase activation through apoptosome formation. Activation of these classical pathways has been shown to occur in macrophages with experimental evidence implicating the following: Bim [92], Bax [93], FasL [94], caspases [95], p53 [96], Poly (ADP-ribose) polymerase (PARP)-1 [97], peroxisome proliferator-activated receptor (PPAR)- $\alpha / \gamma$ [98], migration inhibitory factor (MIF) [99], matrix metallo-proteinases (MMPs) [100], Cathepsin L/K [101, 102], lipoprotein-associated phospholipase A2 (Lp-PLA2) [103], ox-LDL [104] and oxysterols [105].

Ox-LDL has been implicated as a key initiator in a number of plaque promoting processes [106] including the induction of macrophage apoptosis, ROS generation, Fas
Fig. 2 Factors involved in macrophage apoptosis in atherosclerosis: Macrophage apoptosis in atherosclerosis can be mediated by a number of factors that activate both the intrinsic and extrinsic pathways. Many of these factors act through the induction of oxidative or ER stress. A number of pro-apoptotic mediators are indicated along with the receptors to which they bind. Clearance of apoptotic macrophages is impaired by ox-LDL, advanced lesion stage and results in increased necrosis and plaque instablility

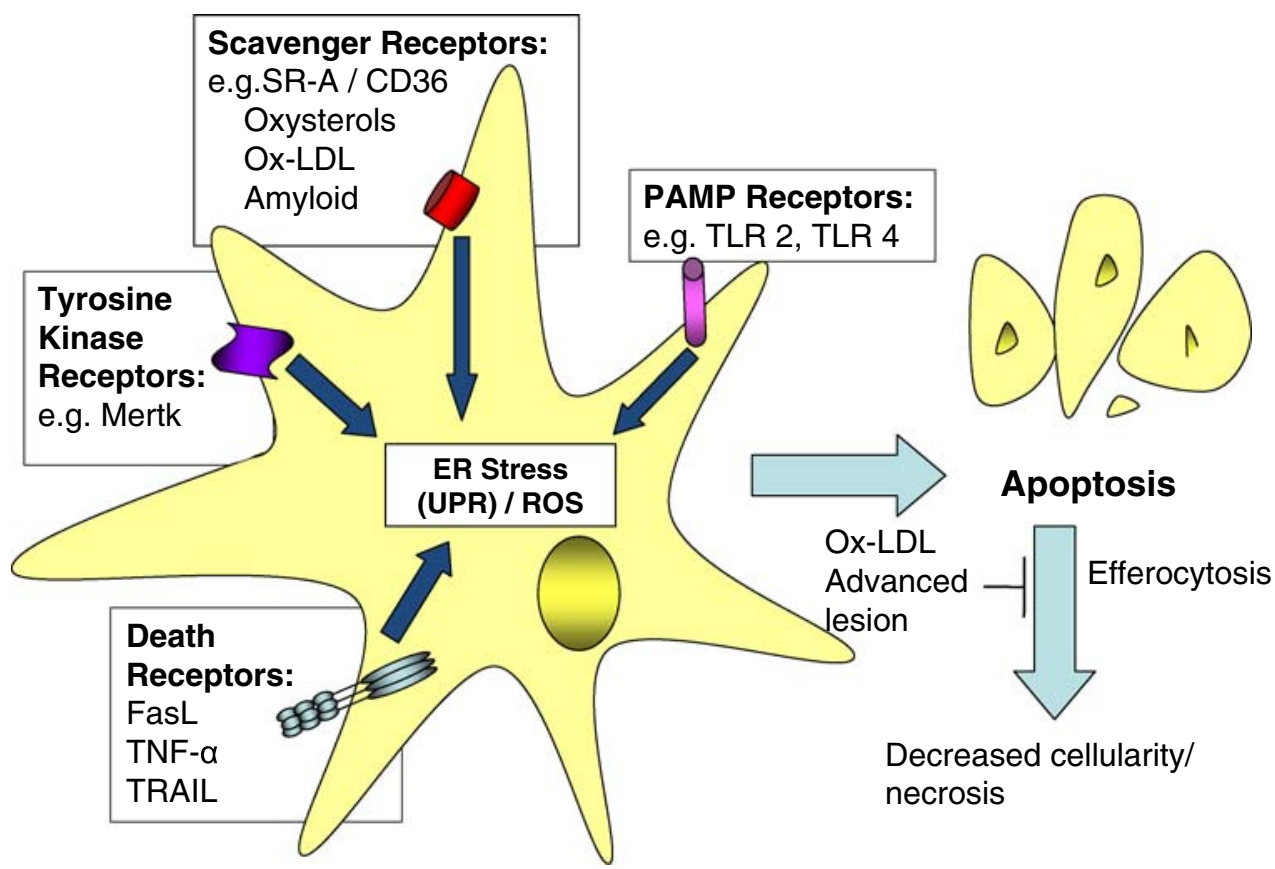


receptor activation and activation of the intrinsic mitochondrial pathway involving Bcl-2, cytochrome $\mathrm{c}$ and caspase-3. The targeting of multiple pathways by ox-LDL underlines the importance of what has been proven in epidemiological studies to be a key risk factor clinically for cardiovascular disease. In addition, these data highlight the complexity of atheropathogenesis, with the likelihood that a multiple hit hypothesis rather than a single event is important in terms of disease progression.

Balancing pro-apototic factors are a series of inhibitors of this process which include: Bcl-2 [107], macrophage colony-stimulating factor (M-CSF) [108], tissue inhibitors of metalloproteinases (TIMPs) [109], survivin [108], TOSO [110], FLICE-like inhibitory protein (FLIP) [111], Bfl-1, and Mcl-1 [112]. The importance of considering the temporal aspects of macrophage apoptosis in atherosclerosis is illustrated by recent work on survivin, a caspase inhibitor of the inhibitors of apoptosis (IAP) family, which is transcribed specifically during mitosis and is usually absent in normal adult tissues. Survivin expression seemed confined to $\mathrm{CD}^{+} 8^{+}$macrophages infiltrating early fatty streaks but was not detected in advanced lesions, which may indicate a biphasic role in the disease pathogenesis. Initial expression of survivin may promote macrophage accumulation in the vascular wall and plaque progression, while subsequent loss of survivin may contribute to plaque instability and apoptosis. Interestingly, one of the factors that led to decreased survivin expression in this study was ox-LDL, indicating another potential mechanism by which prolonged incubation with oxidised lipid contributes to macrophage apoptosis.

Activation of ER stress signalling pathways occurs following exposure to many of the risk factors for atherosclerosis and usually represents a protective response, for example protection against the accumulation of misfolded proteins. It is likely therefore that activation of these pathways acts in concert with many of the other mechanisms mentioned above. There are numerous potential causes of ER stress that have been implicated in atheropathogenesis, examples of which include: oxysterol [105], NO [113], ubiquitin-proteasome system (UPS) [114], insulin resistance [115], unfolded protein response (UPR) [116], forkhead transcription factor (FoxO)1 [117], calcium [118], 7-ketocholesterol [119], NADPH oxidase [120]. Insulin resistance is a well documented risk factor for atherosclerosis, however the exact mechanism remains unknown. Studies of mice with insulin receptor deficient macrophages have shown diminished Akt phosphorylation and an augmented ER stress response, leading to the induction of macrophage scavenger receptor A (SR-A) and increased apoptosis when challenged with cholesterol loading or nutrient deprivation. Furthermore, it has been shown that a major underlying mechanism involves increased activity of FoxO transcription factors. FoxO1 induces expression of $\mathrm{I} \kappa \mathrm{B}$, blunting the p65/NF- $\kappa \mathrm{B}$ response that is characteristic of the response of maladaptive proteins to ER stress, with proapoptotic and antiinflammatory consequences.

In order to enter the subendothelial space, blood monocytes must cross the vascular endothelium where differentiation into macrophages occurs. Leukocyte and endothelial cell adhesion molecules such as intercellular adhesion molecule-1, vascular cell adhesion molecule-1 (VCAM-1), very late-acting antigen-4 (VLA-4), P-selectin, L-selectin, and CD18, along with chemoattractants such as monocyte chemotactic protein-1 (MCP-1), are involved in this process to differing degrees, depending on a variety of circumstances. It would therefore follow that these factors would play a role in atheropathogenesis. There is some experimental evidence to show that targeting chemotactic factors and adhesion molecules does decrease plaque size and macrophage infiltration without affecting plasma lipid levels [121]. Furthermore, activation of macrophage receptors, apart from those mentioned as part of the extrinsic apoptotic pathway, have been shown to promote macrophage apoptosis in models of atherosclerosis. These receptors include: LDL receptor-1 (LOX-1) [122], SR-A, CD36 [123], toll-like receptors (TLRs) [124, 125], canabinoid 2 (CB2) receptor [126], Mertk [127], prostaglandin receptor EP-4 [128], TNFR [129], interleukin-1 receptor-associated kinase (IRAK) [130], and phospholipase C (PLC)- $\beta$ [131].

Over 30 years ago it was discovered that macrophages can take up and degrade modified LDL. Since then cloning studies have revealed multiple scavenger receptors that can endocytose modified LDL [132]. These receptors have been shown in-vitro to drive foam cell formation, and more recently to be involved in pro-apoptotic signalling. These studies again demonstrate the convergence of several different mechanisms in the induction of apoptosis in macrophages. Namely, the activation of SR-A and TLR4 by SR-A ligands, combined with CD36 and TLR2 activation by oxidised phospholipids in ER-stressed macrophages. Examples of ligands binding such receptors and triggering apoptosis have included modified LDL, advanced glycation end-products, $\beta$-amyloid and bacterial products. In insulin-resistant macrophages both CD36 and SR-A are post-transcriptionally upregulated by distinct mechanisms. Increased expression of CD36 is associated with enhanced recycling of the receptor to the cell surface, and to defective macrophage PI3 $\mathrm{K}$ activity resulting in decreased Akt phosphorylation [133]. Insulin resistance acts on multiple targets to promote atherosclerosis, via dyslipidaemia (increased VLDL, decreased HDL), hypertension, a hypercoagulable state, endothelial dysfunction, and increased smooth muscle proliferation. This ineffective 
insulin signalling therefore affects all cells of the arterial wall, including macrophages, with insulin resistant macrophages being more susceptible to ER stress and apoptosis in response to ox-LDL [134]. Again a convergence of various different mechanisms can be seen to promote apoptosis of insulin-resistant macrophages including increased ER stress, scavenger receptor and TLR activation and oxidative stress, combined with decreased Akt signalling. However, it must be emphasised that abnormal Akt activity, even in the absence of insulin resistance, may lead to endothelial dysfunction and is associated with increased expression of inflammatory cytokines, adhesion molecules and accelerated atherosclerosis [135]. Other signalling pathways implicated in macrophage apoptosis in atheropathogenesis include: ERK/MAP kinase [136], NF- $\kappa \mathrm{B}$ [137], AP-1, c-JUN, c-FOS [138], JNK, STAT1, p53 [139], TRAIL [129].

From an early stage in atheropathogenesis it is clear that ox-LDL plays an important role in plaque development. In contrast to the extensive accumulation of cholesterol fatty acid esters in early lesional macrophage foam cells, macrophages in advanced atherosclerotic lesions show accumulation of large amounts of free cholesterol (FC), presumably caused by failed cholesterol esterification by acyl Co-A: cholesterol acyltransferase (ACAT) and diminished cholesterol efflux. Both of these factors can induce apoptosis in cultured macrophages and there is evidence to support this effect in plaque development. However, the form in which this lipid occurs has also been shown to be important, with minimally oxidised LDL, common in early lesions, countering ox-LDL-induced and FC-induced apotosis via Akt-dependent process both in culture and in vivo [140]. Indicating that at an early stage this process may contribute to foam cell proliferation and lesion development.

The importance of lesion stage on macrophage apoptosis was highlighted above. Processes that decrease macrophage accumulation at an early stage, such as apoptosis coupled with phagocytic clearance, can inhibit lesion progression. In advanced lesions macrophage apoptosis that proceeds at a rate that exceeds that of phagocytic clearance further increases local inflammation and tissue destruction, leading to expansion of the necrotic core and to the formation of an unstable plaque [141]. Furthermore, it is likely that in such a proinflammatory cytokine milieu the M1 proinflammatory macrophage phenotype predominates rather than the M2 pro-resolution phenotype [142]. As discussed above, ox-LDL plays a key role in plaque development via multiple different mechanisms. Ox-LDL has also been shown to inhibit efferocytosis whilst encouraging lipid uptake, in a process that involves TLR activation [143]. Other receptors implicated in macrophage efferocytosis in atherosclerosis include: Mertk [127, 144], apolipoprotein $\mathrm{E}(\mathrm{APO} \varepsilon)$, Fas, transglutaminase-2, complement protein $\mathrm{C} 1 \mathrm{q}$ and lactadherin [145].

Diabetic nephropathy

Diabetic nephropathy is the commonest cause of end-stage renal disease (ESRD) worldwide and affects $25-40 \%$ of patients with diabetes [146]. Early alterations in DN include glomerular hyperfiltration, glomerular and tubular epithelial hypertrophy and the development of microalbuminuria. This is followed by glomerular basement membrane thickening, accumulation of mesangial matrix, overt proteinuria and progressive loss of kidney mass associated with the development of glomerulosclerosis and tubulointerstitial fibrosis (TIF) leading to ESRD [147]. A recent study has demonstrated sixfold higher levels of apoptosis in glomeruli of T2DM patients with DN, and a threefold increase in apoptotic cells in kidney tubules when compared to normal controls [148]. Although mesangial cells and podocytes have been proposed as the major targets of cell damage in DN, a growing body of evidence suggests that inflammatory processes and immune cells are involved in both disease initiation and progression. Increased monocytes/macrophages have been reported in glomeruli of patients with DN [149, 150]. In addition, increased expression of cytokines including IL-6 and MCP-1 have also been reported in diabetic glomeruli [151]. These cytokines may mediate monocyte/macrophage infiltration.

Renal fibrosis is the inevitable consequence of an excessive accumulation of extracellular matrix that occurs in virtually every type of chronic kidney disease (CKD). Progression of kidney disease, irrespective of the initial cause, often results in widespread scarring with complete destruction of renal parenchyma. Underlying cellular events in this process are complicated and include: mesangial and fibroblast activation, fibrocyte recruitment, tubular epithelial-mesenchymal transformation (EMT), macrophage and $\mathrm{T}$ cell activation and apoptotic events [152]. TGF- $\beta 1$ plays a key role in regulating the pathological changes of DN that lead to tubulointerstitial fibrosis (TIF), interstitial myofibroblast activation, transformation of tubular epithelia into myofibroblasts and increased connective tissue growth factor (CTGF) expression. TGF- $\beta 1$ has also been impliacted in mediating some of the pro-fibrotic effects of the renin-angiotensin-aldosterone (RAAS) pathway activation [153]. Targeting such a mediator for therapeutic intervention would seem attractive, however, due to the pleiotropic effects of TGF- $\beta 1$, direct modulation is not possible. As such there has been some interest in generating modulators of specific targets of TGF- $\beta 1$ signalling reported to be involved in DN. These include Smad7, bone morphogenetic protein (BMP) 7, CTGF, 
hepatocyte growth factor (HGF) and more recently induced in high glucose-1 (IHG-1) [154]. IHG-1 is a mitochondrial protein upregulated by high extracellular glucose concentrations, the exact function of which remains unknown. Murphy et al. present evidence of upregulation of IHG-1 in renal biopsies in patients with $\mathrm{DN}$ and in an in vivo model of renal fibrosis. Importantly IHG-1 was found to amplify TFG- $\beta 1$-dependent signalling by increasing phosphorylation of Smad3.

In principle, renal fibrosis represents a failed wound healing process of the kidney after chronic sustained injury. Important cell types in this process include macrophages and T cells. Macrophages are an important source of TGF$\beta 1$ and induce fibroblast activation with deposition of excess extra-cellular matrix. During fibrosis, tissue structure alters such that capillary blood supply may be lost, further increasing oxidative stress, hypoxia and inflammation, unless adequate neo-vascularisation occurs and it is in this setting that the persistence of macrophages and lymphocytes play a prominent role [155].

Exploring the role of macrophages in renal disease has led many investigators to consider manipulation of factors that attract these cells to the site of injury. One such approach involved using a chemokine receptor (CCR)1 antagonist, which has been shown to provide protection from tubulointerstitial injury without impacting glomerular pathology or proteinuria in $\mathrm{db} / \mathrm{db}$ mice [156]. This was attributed to decreased recruitment of macrophages to the renal interstitium. Decreased renal recruitment of macrophages in $\mathrm{SR}-\mathrm{A}^{-1-}$ diabetic mice relative to wild type controls has also been demonstrated and this was associated with resistance to $\mathrm{DN}$ and reduced microinflammation [157]. MCP-1 and chemokine ligand 2 (CCL2) have been proposed as novel diagnostic markers and therapeutic targets for DN [158]. It should at the same time be emphasised that recent experimental work has elucidated the apparent heterogeneity in the macrophage population, namely the M1 and M2 phenotype as mentioned earlier. Although macrophages are widely recognised as contributing to the pathogenesis of renal fibrosis, they may also play beneficial reparative and remodelling roles during tissue repair [159] Whether a particular macrophage phenotype is beneficial is dependent on the phase of inflammation, M1 macrophages may induce apoptosis of host tissue cells through release of proinflammatory mediators such as $\mathrm{TNF}-\alpha$ thereby inducing tissue injury, however apoptotic cells are rapidly recognised by macrophages with this process promoting differentiation into the M2 phenotype. Wang et al. polarised macrophages in vitro to an M2 phenotype by stimulating with IL-4/IL-13. Adoptive transfer of these M2-polarised macrophages by systemic injection after the onset of chronic inflammatory renal disease, promoted downregulation of inflammatory cytokine and chemokine expression by host infiltrating macrophages and limited tissue destruction [160]. Therefore promoting such a process may serve to promote resolution by encouraging nonphlogistic phagocytosis of apoptotic cells, an example of which is the use of lipoxins which have been shown to encourage efferocytosis of apoptotic neutrophils [161], promote resolution of mesangioproliferative nephritis [162], protect from ischaemic acute renal failure [163], and show pro-resolution properties in other in vivo models of inflammation [164].

Activated T cells are also associated with DN. T cell accumulation has been reported in the juxtaglomerular apparatus of patients with type 1 diabetes [165]. Expression of the adhesion molecules lymphocyte-function-associated antigen-1 and ICAM-1 is found on renal epithelial, endothelial and mesangial cells. Interaction with these adhesion molecules would facilitate $\mathrm{T}$ cell migration into the kidney. Secretion of proinflammatory cytokines such as IFN- $\gamma$ by $\mathrm{T}$ cells would increase inflammation and oxidative stress within the kidney.

\section{Diabetic retinopathy}

Diabetic retinopathy (DR) is the most common cause of blindness in the working population and with time, occurs in nearly all patients with T1DM and in more than half of patients suffering from T2DM [166]. Although clinical trials have shown that good glycaemic control can reduce the development of DR [167, 168], studies reveal that vision threatening retinopathy usually occurs as a result of neovascularisation in type 1 and maculopathy in type 2 patients [169, 170]. Retinal complications arise from neurological abnormalities, metabolic imbalance and microvascular dysfunction reflecting endothelial cell dysfunction, vessel leakage and occlusions. Current therapeutic modalities are ineffective against restoring diminished visual acuity and rest primarily with good glycaemic and blood pressure control, with laser photocoagulation being reserved for proliferative DR and maculopathy. Greater understanding of the molecular mechanisms involved in DR should therefore yield further therapeutic options. However, to date, although in vivo rodent models and in vitro culture have offered insight into early retinopthy, there is currently no reliable model for proliferative retinopathy [171, 172].

Diabetic retinopathy represents the combined effect of numerous biochemical alterations that occur due to high glucose and that take place in the retina, in particular the vascular endothelial cells and pericytes. The retinal endothelial cells incorporate glucose via glucose transporter-1 [173], leading to intracellular accumulation of glucose which leads to the activation of various pathways, that 
mirror other microvascular complications. This endothelial cell dysfunction arises as a result of impaired NO bioavailability, oxidative stress and increased polyol pathway activation and AGE formation, which in combination lead to activation of intracellular signalling pathways involving $\mathrm{PKC}, \mathrm{PKB}$, and MAPK, finally culminating in induction of the pro-inflammatory transcription factors such as $\mathrm{NF} \kappa \mathrm{B}$ and AP-1 [174]. TNF- $\alpha$ has also recently been implicated in the loss of retinal microvascular cells that occurs early in the pathogenesis of DR [175]. This study demonstrated that intravitreal injection of the TNF-specific inhibitor pegsunercept reduced the number of apoptotic endothelial cells, pericytes and microvascular cells in models of both T1DM (STZ rats) and T2DM (Zucker diabetic fatty rats).

$\mathrm{NF}-\kappa \mathrm{B}$ is a widely expressed inducible transcription factor that is an important regulator of many genes involved in mammalian inflammatory and immune responses, proliferation and apoptosis. Evidence supporting the role of NF- $\kappa \mathrm{B}$ in the early stages of DR comes from studies in which proteins, whose expression is regulated by $\mathrm{NF}-\kappa \mathrm{B}$, such as iNOS and ICAM, were inhibited [176, 177]. Inhibition of these proteins prevents diabetes-induced apoptosis of retinal capillaries. In addition, compounds which inhibit NF- $\kappa$ B such as aspirin, which forms part of the therapeutic armamentarium, also block DR development [178].

\section{Diabetic neuropathy}

Diabetic neuropathy affects over 50\% of patients with diabetes and represents the most common cause of foot ulcers and non-traumatic amputations in the western world [179]. Although there has been significant progress in the understanding of the clinical aspects of these conditions, many questions remain unanswered in terms of causation, risk factors, genetic susceptibility, effective treatments, restoration of nerve functions and pain management. The major handicap in studying diabetic neuropathies is the lack of a suitable animal model that addresses both the acute and chronic events in its pathogenesis. In common with other microvascular complications of diabetes, the major risk factors are glycaemic control and duration of diabetes and there are no other treatments to slow the progression or delay the development of diabetic neuropathy [180]. The pathogenesis reflects a multifactorial aetiology that involves both hyperglycaemia-induced damage to nerve cells and axons, and neuronal ischemia caused by hyperglycaemia-induced decreases in neurovascular flow [181]. Analagous to the molecular mechanisms behind $\mathrm{DN}$, a combination of oxidative stress and hyperglycaemia activate the detrimental pathways of AGE, polyol, hexosamine and PKC pathways which lead to redox imbalance, gene expression disturbances, and further oxidative stress and in turn further inflammation and neuronal dysfunction. These pathways combine to result in increased activation of NF- $\kappa \mathrm{B}$ and production of proinflammatory cytokines such as TNF- $\alpha$, further activating local endothelium, increasing inflammatory infiltrate, cytokine release and local tissue damage [182]. Activation of NF- $\kappa \mathrm{B}$ and other transcription factors by high glucose and oxidative stress leads to upregulation of iNOS, cyclooxygenase-2 (Cox-2), cell adhesion molecules and inflammatory genes [183]. More recently the EURODIAB study has further emphasised the importance of inflammation by showing that Hsp27, part of the TNF- $\alpha$ signalling pathway that leads to release of the inflammatory mediators Cox-2, IL-6, and IL-8, was elevated in the blood of diabetic patients with neuropathy [184].

\section{Conclusion}

The loss of pancreatic $\beta$-cells in T1DM occurs as a result of apoptotic signals from high local concentrations of inflammatory cytokines and $\mathrm{T}$ cells in the islet microenvironment. As such, many current treatment strategies are focussed on preventing the destruction of transplanted islets through the induction of apoptosis in graft-specific activated $\mathrm{T}$ cells. Other regimens aim to induce peripheral tolerance by the introduction of anti-inflammatory Tregs into the pancreatic islets or the expansion of resident Tregs in order to suppress the autoimmune destruction of the insulin-producing cells. Similar to T1DM, T2DM is also characterised by progressive loss of $\beta$-cells. Many pathways have been proposed to be involved in this apoptosis including increased circulating cell nutrients and ER stress. However, the infiltration of immune cells has also been implicated. The proinflammatory cytokine IL- $1 \beta$ represents a common mediator of $\beta$-cell death in both T1DM and T2DM.

Diabetic patients have a two to fourfold increased risk of developing microvascular and macrovascular complications and despite the well documented benefits of controlling blood glucose, hypertension and dyslipidaemia, these therapeutic strategies cannot reverse the target organ damage that many diabetic patients encounter. Furthermore, with the expected increase in the prevalence of DM over the next 20 years, new therapeutic options are urgently needed and are best delivered through improved understanding of the molecular mechanisms behind these complications. Diabetic complications arise against a background of dysregulated metabolism, endothelial dysfunction and a pro-inflammatory state that precedes the development of diabetes and its complications. Both the microvascular and macrovascular complications highlight the process that results following failed resolution of 
inflammation after chronic sustained injury arising from dysglycaemia and dyslipidaemia. As outlined in this review, failure to remove apoptotic cells efficiently further contributes to local tissue damage and organ destruction. Effective efferocytosis depends on crosstalk between resident cells, leukocytes and lymphocytes with macrophages playing a key effector role both in tissue destruction and in tissue resolution. The plasticity in terms of cell phenotype is particularly illustrated in terms of the macrophage and its ability to localise to the site of tissue destruction makes it an appealing target for promoting inflammatory resolution in future research.

Acknowledgments Work in the authors laboratory is funded by Science Foundation Ireland, The Health Research Board Ireland and the EU FP6 EICOSANOX Consortium (LSHM-CT-2004-005033). Aidan Ryan is the recipient of a Molecular Medicine Ireland Clinical Research Fellowship

\section{References}

1. Rossini AA, Mordes JP, Like AA (1985) Immunology of insulin-dependent diabetes mellitus. Annu Rev Immunol 3:289-320. doi:10.1146/annurev.iy.03.040185.001445

2. Kahn SE (2001) Clinical review 135: the importance of beta-cell failure in the development and progression of type 2 diabetes. J Clin Endocrinol Metab 86:4047-4058. doi:10.1210/jc.86.9.4047

3. Kahn BB, Flier JS (2000) Obesity and insulin resistance. J Clin Invest 106:473-481. doi:10.1172/JCI10842

4. Brownlee M (2001) Biochemistry and molecular cell biology of diabetic complications. Nature 414:813-820. doi:10.1038/ 414813a

5. Nishikawa T, Edelstein D, Du XL et al (2000) Normalizing mitochondrial superoxide production blocks three pathways of hyperglycaemic damage. Nature 404:787-790. doi:10.1038/ 35008121

6. Mehta JL, Rasouli N, Sinha AK, Molavi B (2006) Oxidative stress in diabetes: a mechanistic overview of its effects on atherogenesis and myocardial dysfunction. Int $\mathrm{J}$ Biochem Cell Biol 38:794-803. doi:10.1016/j.biocel.2005.12.008

7. Borst SE (2004) The role of TNF-alpha in insulin resistance. Endocr 23:177-182. doi:10.1385/ENDO:23:2-3:177

8. Jager J, Gremeaux T, Cormont M, Le Marchand-Brustel Y, Tanti JF (2007) Interleukin-1beta-induced insulin resistance in adipocytes through down-regulation of insulin receptor substrate-1 expression. Endocrinology 148:241-251. doi:10.1210/ en.2006-0692

9. Senn JJ, Klover PJ, Nowak IA, Mooney RA (2002) Interleukin-6 induces cellular insulin resistance in hepatocytes. Diabetes 51:3391-3399. doi:10.2337/diabetes.51.12.3391

10. Navarro-Gonzalez JF, Mora-Fernandez C (2008) The role of inflammatory cytokines in diabetic nephropathy. J Am Soc Nephrol 19:433-442. doi:10.1681/ASN.2007091048

11. Riboulet-Chavey A, Diraison F, Siew LK, Wong FS, Rutter GA (2008) Inhibition of AMP-activated protein kinase protects pancreatic beta-cells from cytokine-mediated apoptosis and CD8+ T-cell-induced cytotoxicity. Diabetes 57:415-423. doi: $10.2337 / \mathrm{db} 07-0993$

12. Butler AE, Janson J, Bonner-Weir S et al (2003) Beta-cell deficit and increased beta-cell apoptosis in humans with type 2 diabetes. Diabetes 52:102-110. doi:10.2337/diabetes.52.1.102
13. Sjoholm A, Nystrom T (2006) Inflammation and the etiology of type 2 diabetes. Diabetes Metab Res Rev 22:4-10. doi: $10.1002 /$ dmrr.568

14. Maedler K, Sergeev P, Ris F et al (2002) Glucose-induced beta cell production of IL-1beta contributes to glucotoxicity in human pancreatic islets. J Clin Invest 110:851-860

15. Delovitch TL, Singh B (1997) The nonobese diabetic mouse as a model of autoimmune diabetes: immune dysregulation gets the NOD. Immunity 7:727-738. doi:10.1016/S1074-7613(00) 80392-1

16. Wicker LS, Todd JA, Peterson LB (1995) Genetic control of autoimmune diabetes in the NOD mouse. Annu Rev Immunol 13:179-200. doi:10.1146/annurev.iy.13.040195.001143

17. Mandrup-Poulsen T (2003) Apoptotic signal transduction pathways in diabetes. Biochem Pharmacol 66:1433-1440. doi: 10.1016/S0006-2952(03)00494-5

18. Lee SC, Pervaiz S (2007) Apoptosis in the pathophysiology of diabetes mellitus. Int J Biochem Cell Biol 39:497-504. doi: 10.1016/j.biocel.2006.09.007

19. Hui H, Dotta F, Di Mario U, Perfetti R (2004) Role of caspases in the regulation of apoptotic pancreatic islet beta-cells death. J Cell Physiol 200:177-200. doi:10.1002/jcp.20021

20. Cnop M, Welsh N, Jonas JC et al (2005) Mechanisms of pancreatic beta-cell death in type 1 and type 2 diabetes: many differences, few similarities. Diabetes 54(Suppl 2):S97-S107. doi:10.2337/diabetes.54.suppl_2.S97

21. Brodie GM, Wallberg M, Santamaria P, Wong FS, Green EA (2008) B-cells promote intra-islet CD8+ cytotoxic T-cell survival to enhance type 1 diabetes. Diabetes 57:909-917. doi: $10.2337 / \mathrm{db} 07-1256$

22. Trudeau JD, Kelly-Smith C, Verchere CB et al (2003) Prediction of spontaneous autoimmune diabetes in NOD mice by quantification of autoreactive T cells in peripheral blood. J Clin Invest 111:217-223

23. Lenschow DJ, Walunas TL, Bluestone JA (1996) CD28/B7 system of T cell costimulation. Annu Rev Immunol 14:233-258. doi:10.1146/annurev.immunol.14.1.233

24. Kagi D, Odermatt B, Seiler P et al (1997) Reduced incidence and delayed onset of diabetes in perforin-deficient nonobese diabetic mice. J Exp Med 186:989-997. doi:10.1084/jem. 186.7 .989

25. Eizirik DL, Mandrup-Poulsen T (2001) A choice of death-the signal-transduction of immune-mediated beta-cell apoptosis. Diabetologia 44:2115-2133. doi:10.1007/s001250100021

26. Stephens LA, Thomas HE, Ming L et al (1999) Tumor necrosis factor-alpha-activated cell death pathways in NIT-1 insulinoma cells and primary pancreatic beta cells. Endocrinology 140:3219-3227. doi:10.1210/en.140.7.3219

27. Eizirik DL, Flodstrom M, Karlsen AE, Welsh N (1996) The harmony of the spheres: inducible nitric oxide synthase and related genes in pancreatic beta cells. Diabetologia 39:875-890. doi:10.1007/BF00403906

28. Papaccio G, Graziano A, D'Aquino R, Valiante S, Naro F (2005) A biphasic role of nuclear transcription factor (NF)kappaB in the islet beta-cell apoptosis induced by interleukin (IL)-1beta. J Cell Physiol 204:124-130. doi:10.1002/jcp.20276

29. McKenzie MD, Dudek NL, Mariana L et al (2006) Perforin and Fas induced by IFNgamma and TNFalpha mediate beta cell death by OT-I CTL. Int Immunol 18:837-846. doi:10.1093/ intimm/dx1020

30. Wachlin G, Augstein P, Schroder D et al (2003) IL-1beta, IFNgamma and TNF-alpha increase vulnerability of pancreatic beta cells to autoimmune destruction. J Autoimmun 20:303-312. doi: 10.1016/S0896-8411(03)00039-8

31. Kwon G, Xu G, Marshall CA, McDaniel ML (1999) Tumor necrosis factor alpha-induced pancreatic beta-cell insulin 
resistance is mediated by nitric oxide and prevented by 15 deoxy-Delta12, 14-prostaglandin J2 and aminoguanidine. A role for peroxisome proliferator-activated receptor gamma activation and inos expression. J Biol Chem 274:18702-18708. doi: 10.1074/jbc.274.26.18702

32. Kim WH, Lee JW, Gao B, Jung MH (2005) Synergistic activation of JNK/SAPK induced by TNF-alpha and IFN-gamma: apoptosis of pancreatic beta-cells via the p53 and ROS pathway. Cell Signal 17:1516-1532. doi:10.1016/j.cellsig.2005.03.020

33. Maedler K, Spinas GA, Dyntar D et al (2001) Distinct effects of saturated and monounsaturated fatty acids on beta-cell turnover and function. Diabetes 50:69-76. doi:10.2337/diabetes.50.1.69

34. Roehrich ME, Mooser V, Lenain V et al (2003) Insulin-secreting beta-cell dysfunction induced by human lipoproteins. J Biol Chem 278:18368-18375. doi:10.1074/jbc.M300102200

35. Harding HP, Ron D (2002) Endoplasmic reticulum stress and the development of diabetes: a review. Diabetes 51(Suppl 3):S455-S461. doi:10.2337/diabetes.51.2007.S455

36. Zhao YF, Feng DD, Chen C (2006) Contribution of adipocytederived factors to beta-cell dysfunction in diabetes. Int $\mathrm{J}$ Biochem Cell Biol 38:804-819. doi:10.1016/j.biocel.2005.11.008

37. Boni-Schnetzler MML, Ehses JA, Weir GC, Donath MY (2007) IL-1beta expression is induced by glucose and IL-1beta autostimulation, and increased in beta cells of type 2 diabetics. Diabetes 56:A413 Abstract

38. Larsen CM, Faulenbach M, Vaag A et al (2007) Interleukin-1receptor antagonist in type 2 diabetes mellitus. N Engl J Med 356:1517-1526. doi:10.1056/NEJMoa065213

39. Hull RL, Westermark GT, Westermark P, Kahn SE (2004) Islet amyloid: a critical entity in the pathogenesis of type 2 diabetes. J Clin Endocrinol Metab 89:3629-3643. doi:10.1210/jc.2004-0405

40. Marzban L, Park K, Verchere CB (2003) Islet amyloid polypeptide and type 2 diabetes. Exp Gerontol 38:347-351. doi: 10.1016/S0531-5565(03)00004-4

41. Homo-Delarche F, Calderari S, Irminger JC et al (2006) Islet inflammation and fibrosis in a spontaneous model of type 2 diabetes, the GK rat. Diabetes 55:1625-1633. doi:10.2337/ $\mathrm{db} 05-1526$

42. Ehses JA, Perren A, Eppler E et al (2007) Increased number of islet-associated macrophages in type 2 diabetes. Diabetes 56:2356-2370. doi:10.2337/db06-1650

43. Dai YD, Carayanniotis G, Sercarz E (2005) Antigen processing by autoreactive B cells promotes determinant spreading. Cell Mol Immunol 2:169-175

44. Gruessner RW, Sutherland DE, Najarian JS, Dunn DL, Gruessner AC (1997) Solitary pancreas transplantation for nonuremic patients with labile insulin-dependent diabetes mellitus. Transplantation 64:1572-1577. doi:10.1097/00007890199712150-00011

45. Ryan EA, Paty BW, Senior PA et al (2005) Five-year follow-up after clinical islet transplantation. Diabetes 54:2060-2069. doi: 10.2337/diabetes.54.7.2060

46. Nir T, Melton DA, Dor Y (2007) Recovery from diabetes in mice by beta cell regeneration. J Clin Invest 117:2553-2561. doi:10.1172/JCI32959

47. Kang SM, Schneider DB, Lin Z et al (1997) Fas ligand expression in islets of Langerhans does not confer immune privilege and instead targets them for rapid destruction. Nat Med 3:738-743. doi:10.1038/nm0797-738

48. Hsu PN, Lin HH, Tu CF et al (2001) Expression of human Fas ligand on mouse beta islet cells does not induce insulitis but is insufficient to confer immune privilege for islet grafts. J Biomed Sci 8:262-269. doi:10.1007/BF02256600

49. Lin B, Zhang ZL, Yu LY, Guo LH (2003) CMV-hFasL transgenic mice are sensitive to low doses of streptozotocin-induced type I diabetes mellitus. Acta Pharmacol Sin 24:1199-1204
50. Sakata M, Yasuda H, Moriyama H et al (2008) Prevention of recurrent but not spontaneous autoimmune diabetes by transplanted NOD islets adenovirally transduced with immunomodulating molecules. Diabetes Res Clin Pract 80:352359. doi:10.1016/j.diabres.2008.01.030

51. Lamhamedi-Cherradi SE, Zheng S, Tisch RM, Chen YH (2003) Critical roles of tumor necrosis factor-related apoptosis-inducing ligand in type 1 diabetes. Diabetes 52:2274-2278. doi: 10.2337/diabetes.52.9.2274

52. Ou D, Metzger DL, Wang X et al (2002) TNF-related apoptosisinducing ligand death pathway-mediated human beta-cell destruction. Diabetologia 45:1678-1688. doi:10.1007/s00125002-0926-2

53. Ou D, Wang X, Metzger DL et al (2005) Synergistic inhibition of tumor necrosis factor-related apoptosis-inducing ligandinduced apoptosis in human pancreatic beta cells by Bcl-2 and $\mathrm{X}$-linked inhibitor of apoptosis. Hum Immunol 66:274-284. doi: 10.1016/j.humimm.2004.12.002

54. Sanlioglu AD, Dirice E, Elpek O et al (2008) High levels of endogenous tumor necrosis factor-related apoptosis-inducing ligand expression correlate with increased cell death in human pancreas. Pancreas 36:385-393. doi:10.1097/MPA.0b013e $318158 \mathrm{a} 4 \mathrm{e} 5$

55. Moore KW, 1 Malefyt R, Coffman RL, O’Garra A (2001) Interleukin-10 and the interleukin-10 receptor. Annu Rev Immunol 19:683-765. doi:10.1146/annurev.immunol.19.1.683

56. Szelachowska M, Kretowski A, Kinalska I (1998) Decreased in vitro IL-4 [corrected] and IL-10 production by peripheral blood in first degree relatives at high risk of diabetes type-I. Horm Metab Res 30:526-530. doi:10.1055/s-2007-978926

57. Alleva DG, Pavlovich RP, Grant C, Kaser SB, Beller DI (2000) Aberrant macrophage cytokine production is a conserved feature among autoimmune-prone mouse strains: elevated interleukin (IL)-12 and an imbalance in tumor necrosis factor-alpha and IL10 define a unique cytokine profile in macrophages from young nonobese diabetic mice. Diabetes 49:1106-1115. doi:10.2337/ diabetes.49.7.1106

58. Smith DK, Korbutt GS, Suarez-Pinzon WL et al (1997) Interleukin-4 or interleukin-10 expressed from adenovirustransduced syngeneic islet grafts fails to prevent beta cell destruction in diabetic NOD mice. Transplantation 64:1040 1049. doi:10.1097/00007890-199710150-00017

59. Tarbell KV, Petit L, Zuo X et al (2007) Dendritic cell-expanded, islet-specific $\mathrm{CD} 4+\mathrm{CD} 25+\mathrm{CD} 62 \mathrm{~L}+$ regulatory $\mathrm{T}$ cells restore normoglycemia in diabetic NOD mice. J Exp Med 204:191-201. doi:10.1084/jem.20061631

60. Long ET, Wood KJ (2007) Regulatory T cells-a journey from rodents to the clinic. Front Biosci 12:4042-4049. doi:10.2741/ 2370

61. Luo X, Tarbell KV, Yang H et al (2007) Dendritic cells with TGF-beta1 differentiate naive CD4+ CD25-T cells into isletprotective Foxp3+ regulatory T cells. Proc Natl Acad Sci USA 104:2821-2826. doi:10.1073/pnas.0611646104

62. Caro JJ, Ward AJ, O'Brien JA (2002) Lifetime costs of complications resulting from type 2 diabetes in the U.S. Diabetes Care 25:476-481. doi:10.2337/diacare.25.3.476

63. Navarro JF, Mora C, Maca M, Garca J (2003) Inflammatory parameters are independently associated with urinary albumin in type 2 diabetes mellitus. Am J Kidney Dis 42:53-61. doi: 10.1016/S0272-6386(03)00408-6

64. Joussen AM, Poulaki V, Le ML et al (2004) A central role for inflammation in the pathogenesis of diabetic retinopathy. FASEB J 18:1450-1452

65. Satoh J, Yagihashi S, Toyota T (2003) The possible role of tumor necrosis factor-alpha in diabetic polyneuropathy. Exp Diabesity Res 4:65-71 
66. Nassar H, Kantarci A, van Dyke TE (2007) Diabetic periodontitis: a model for activated innate immunity and impaired resolution of inflammation. Periodontol 2000 43:233-244. doi: 10.1111/j.1600-0757.2006.00168.x

67. Peleg AY, Weerarathna T, McCarthy JS, Davis TM (2007) Common infections in diabetes: pathogenesis, management and relationship to glycaemic control. Diabetes Metab Res Rev 23:3-13. doi:10.1002/dmrr.682

68. Joshi N, Caputo GM, Weitekamp MR, Karchmer AW (1999) Infections in patients with diabetes mellitus. $\mathrm{N}$ Engl J Med 341:1906-1912. doi:10.1056/NEJM199912163412507

69. Finney SJ, Zekveld C, Elia A, Evans TW (2003) Glucose control and mortality in critically ill patients. JAMA 290:2041-2047. doi:10.1001/jama.290.15.2041

70. Alba-Loureiro TC, Munhoz CD, Martins JO et al (2007) Neutrophil function and metabolism in individuals with diabetes mellitus. Braz J Med Biol Res 40:1037-1044. doi:10.1590/ S0100-879X2006005000143

71. Glowacka E, Banasik M, Lewkowicz P, Tchorzewski H (2002) The effect of LPS on neutrophils from patients with high risk of type 1 diabetes mellitus in relation to IL-8, IL-10 and IL-12 production and apoptosis in vitro. Scand J Immunol 55:210-217. doi:10.1046/j.1365-3083.2002.01046.x

72. Wang H, Meng QH, Gordon JR, Khandwala H, Wu L (2007) Proinflammatory and proapoptotic effects of methylglyoxal on neutrophils from patients with type 2 diabetes mellitus. Clin Biochem 40:1232-1239. doi:10.1016/j.clinbiochem.2007.07.016

73. Gawlowski T, Stratmann B, Stirban AO, Negrean M, Tschoepe D (2007) AGEs and methylglyoxal induce apoptosis and expression of Mac-1 on neutrophils resulting in platelet-neutrophil aggregation. Thromb Res 121:117-126. doi:10.1016/ j.thromres.2007.03.002

74. Otton R, Soriano FG, Verlengia R, Curi R (2004) Diabetes induces apoptosis in lymphocytes. J Endocrinol 182:145-156. doi:10.1677/joe.0.1820145

75. Tennenberg SD, Finkenauer R, Dwivedi A (1999) Absence of lipopolysaccharide-induced inhibition of neutrophil apoptosis in patients with diabetes. Arch Surg 134:1229-1233. doi:10.1001/ archsurg.134.11.1229 discussion 1233-1224

76. Retnakaran R, Zinman B (2008) Type 1 diabetes, hyperglycaemia, and the heart. Lancet 371:1790-1799. doi:10.1016/S01406736(08)60767-9

77. Mazzone T, Chait A, Plutzky J (2008) Cardiovascular disease risk in type 2 diabetes mellitus: insights from mechanistic studies. Lancet 371:1800-1809. doi:10.1016/S0140-6736 (08)60768-0

78. Milicevic Z, Raz I, Beattie SD et al (2008) Natural history of cardiovascular disease in patients with diabetes: role of hyperglycemia. Diabetes Care 31(Suppl 2):S155-S160. doi:10.2337/ dc08-s240

79. Libby P, Ridker PM, Maseri A (2002) Inflammation and atherosclerosis. Circulation 105:1135-1143. doi:10.1161/hc0902. 104353

80. Platt N, Gordon S (2001) Is the class A macrophage scavenger receptor (SR-A) multifunctional?- the mouse's tale. J Clin Invest 108:649-654

81. Martinet W, Kockx MM, Verh K (2004) Apoptosis in atheroclerosis: implications for plaque destabilization. Acad Geneeskd Belg 66:61-79

82. Zeini M, Lopez-Fontal R, Traves PG, Benito G, Hortelano S (2007) Differential sensitivity to apoptosis among the cells that contribute to the atherosclerotic disease. Biochem Biophys Res Commun 363:444-450. doi:10.1016/j.bbrc.2007.09.004

83. Seimon T, Tabas I (2008) Mechanisms and consequences of macrophage apoptosis in atherosclerosis. J Lipid Res [Epub ahead of print]
84. Arai S, Shelton JM, Chen M et al (2005) A role for the apoptosis inhibitory factor AIM/Spalpha/Api6 in atherosclerosis development. Cell Metab 1:201-213. doi:10.1016/j.cmet.2005.02.002

85. Liu J, Thewke DP, Su YR et al (2005) Reduced macrophage apoptosis is associated with accelerated atherosclerosis in lowdensity lipoprotein receptor-null mice. Arterioscler Thromb Vasc Biol 25:174-179

86. Tedgui A, Mallat Z (2001) Apoptosis as a determinant of atherothrombosis. Thromb Haemost 86:420-426

87. Ohayon J, Finet G, Gharib AM et al (2008) Necrotic core thickness and positive arterial remodeling index: emergent biomechanical factors for evaluating the risk of plaque rupture. Am J Physiol Heart Circ Physiol 295:H717-H727. doi: 10.1152/ajpheart.00005.2008

88. Burke AP, Kolodgie FD, Zieske A et al (2004) Morphologic findings of coronary atherosclerotic plaques in diabetics: a postmortem study. Arterioscler Thromb Vasc Biol 24:12661271. doi:10.1161/01.ATV.0000131783.74034.97

89. Riedl SJ, Salvesen GS (2007) The apoptosome: signalling platform of cell death. Nat Rev Mol Cell Biol 8:405-413. doi: $10.1038 / \mathrm{nrm} 2153$

90. Thorburn A (2004) Death receptor-induced cell killing. Cell Signal 16:139-144. doi:10.1016/j.cellsig.2003.08.007

91. Ravagnan L, Roumier T, Kroemer G (2002) Mitochondria, the killer organelles and their weapons. J Cell Physiol 192:131-137. doi:10.1002/jcp.10111

92. Berthier A, Lemaire-Ewing S, Prunet C et al (2005) 7-Ketocholesterol-induced apoptosis. Involvement of several proapoptotic but also anti-apoptotic calcium-dependent transduction pathways. FEBS J 272:3093-3104. doi:10.1111/j.17424658.2005.04723.x

93. Ermak N, Lacour B, Drueke TB, Vicca S (2008) Role of reactive oxygen species and Bax in oxidized low density lipoproteininduced apoptosis of human monocytes. Atherosclerosis 200:247-256. doi:10.1016/j.atherosclerosis.2007.12.052

94. Yao PM, Tabas I (2000) Free cholesterol loading of macrophages induces apoptosis involving the Fas pathway. J Biol Chem 275:23807-23813. doi:10.1074/jbc.M002087200

95. Sarai M, Hartung D, Petrov A et al (2007) Broad and specific caspase inhibitor-induced acute repression of apoptosis in atherosclerotic lesions evaluated by radiolabeled annexin A5 imaging. J Am Coll Cardiol 50:2305-2312. doi:10.1016/ j.jacc.2007.08.044

96. Mercer J, Figg N, Stoneman V, Braganza D, Bennett MR (2005) Endogenous p53 protects vascular smooth muscle cells from apoptosis and reduces atherosclerosis in ApoE knockout mice. Circ Res 96:667-674. doi:10.1161/01.RES.0000161069. 15577.ca

97. Hans CP, Zerfaoui M, Naura AS, Catling A, Boulares AH (2008) Differential effects of PARP inhibition on vascular cell survival and ACAT-1 expression favouring atherosclerotic plaque stability. Cardiovasc Res 78:429-439. doi:10.1093/cvr/ cvn018

98. Chinetti G, Griglio S, Antonucci M et al (1998) Activation of proliferator-activated receptors alpha and gamma induces apoptosis of human monocyte-derived macrophages. J Biol Chem 273:25573-25580. doi:10.1074/jbc.273.40.25573

99. Chen Z, Sakuma M, Zago AC et al (2004) Evidence for a role of macrophage migration inhibitory factor in vascular disease. Arterioscler Thromb Vasc Biol 24:709-714. doi:10.1161/01. ATV.0000119356.35748.9e

100. Johnson JL, Sala-Newby GB, Ismail Y, Aguilera CM, Newby AC (2008) Low tissue inhibitor of metalloproteinases 3 and high matrix metalloproteinase 14 levels defines a subpopulation of highly invasive foam-cell macrophages. Arterioscler Thromb Vasc Biol 28:1647-1653. doi:10.1161/ATVBAHA.108.170548 
101. Li W, Kornmark L, Jonasson L, Forssell C, Yuan XM (2009) Cathepsin $\mathrm{L}$ is significantly associated with apoptosis and plaque destabilization in human atherosclerosis. Atherosclerosis 202:92-102. doi:10.1016/j.atherosclerosis.2008.03.027

102. Samokhin AO, Wong A, Saftig P, Bromme D (2008) Role of cathepsin $\mathrm{K}$ in structural changes in brachiocephalic artery during progression of atherosclerosis in apoE-deficient mice. Atherosclerosis 200:58-68. doi:10.1016/j.atherosclerosis.2007. 12.047

103. Kolodgie FD, Burke AP, Skorija KS et al (2006) Lipoproteinassociated phospholipase A2 protein expression in the natural progression of human coronary atherosclerosis. Arterioscler Thromb Vasc Biol 26:2523-2529. doi:10.1161/01.ATV. 0000244681.72738.bc

104. Akishima Y, Akasaka Y, Ishikawa Y et al (2005) Role of macrophage and smooth muscle cell apoptosis in association with oxidized low-density lipoprotein in the atherosclerotic development. Mod Pathol 18:365-373. doi:10.1038/modpathol. 3800249

105. Massey JB, Pownall HJ (2006) Structures of biologically active oxysterols determine their differential effects on phospholipid membranes. Biochemistry 45:10747-10758. doi:10.1021/bi0 $60540 \mathrm{u}$

106. Nakajima K, Nakano T, Tanaka A (2006) The oxidative modification hypothesis of atherosclerosis: the comparison of atherogenic effects on oxidized LDL and remnant lipoproteins in plasma. Clin Chim Acta 367:36-47. doi:10.1016/j.cca.2005. 12.013

107. Thorp E, Li Y, Bao L et al (2009) Increased apoptosis in advanced atherosclerotic lesions of Apoe-/- mice lacking macrophage Bcl-2. Arterioscler Thromb Vasc Biol 29(2): $169-172$

108. Blanc-Brude OP, Teissier E, Castier Y et al (2007) IAP survivin regulates atherosclerotic macrophage survival. Arterioscler Thromb Vasc Biol 27:901-907. doi:10.1161/01.ATV.0000 258794.57872.3f

109. Koskivirta I, Rahkonen O, Mayranpaa M et al (2006) Tissue inhibitor of metalloproteinases 4 (TIMP4) is involved in inflammatory processes of human cardiovascular pathology. Histochem Cell Biol 126:335-342. doi:10.1007/s00418-0060163-8

110. Sigruener A, Buechler C, Bared SM et al (2007) E-LDL upregulates TOSO expression and enhances the survival of human macrophages. Biochem Biophys Res Commun 359:723728. doi:10.1016/j.bbrc.2007.05.169

111. Perlman H, Pagliari LJ, Georganas C et al (1999) FLICEinhibitory protein expression during macrophage differentiation confers resistance to Fas-mediated apoptosis. J Exp Med 190:1679-1688. doi:10.1084/jem.190.11.1679

112. Halvorsen B, Waehre T, Scholz H et al (2005) Interleukin-10 enhances the oxidized LDL-induced foam cell formation of macrophages by antiapoptotic mechanisms. J Lipid Res 46:211219. doi:10.1194/jlr.M400324-JLR200

113. Martinet W, Croons V, Timmermans JP, Herman AG, De Meyer GR (2007) Nitric oxide selectively depletes macrophages in atherosclerotic plaques via induction of endoplasmic reticulum stress. Br J Pharmacol 152:493-500. doi:10.1038/sj.bjp.0707426

114. Versari D, Herrmann J, Gossl M et al (2006) Dysregulation of the ubiquitin-proteasome system in human carotid atherosclerosis. Arterioscler Thromb Vasc Biol 26:2132-2139. doi: 10.1161/01.ATV.0000232501.08576.73

115. Han S, Liang CP, DeVries-Seimon T et al (2006) Macrophage insulin receptor deficiency increases ER stress-induced apoptosis and necrotic core formation in advanced atherosclerotic lesions. Cell Metab 3:257-266. doi:10.1016/j.cmet.2006.02.008
116. Devries-Seimon T, Li Y, Yao PM et al (2005) Cholesterolinduced macrophage apoptosis requires ER stress pathways and engagement of the type A scavenger receptor. J Cell Biol 171:61-73. doi:10.1083/jcb.200502078

117. Senokuchi T, Liang CP, Seimon TA et al (2008) Forkhead transcription factors (FoxOs) promote apoptosis of insulinresistant macrophages during cholesterol-induced endoplasmic reticulum stress. Diabetes 57:2967-2976. doi:10.2337/db080520

118. Deng T, Zhang L, Ge Y, Lu M, Zheng X (2008) Redistribution of intracellular calcium and its effect on apoptosis in macrophages: induction by oxidized LDL. Biomed Pharmacother [Epub ahead of print]

119. Myoishi M, Hao H, Minamino T et al (2007) Increased endoplasmic reticulum stress in atherosclerotic plaques associated with acute coronary syndrome. Circulation 116:1226-1233. doi: 10.1161/CIRCULATIONAHA.106.682054

120. Hayashi T, Juliet PA, Miyazaki A, Ignarro LJ, Iguchi A (2007) High glucose downregulates the number of caveolae in monocytes through oxidative stress from NADPH oxidase: implications for atherosclerosis. Biochim Biophys Acta 1772:364-372

121. Husemann J, Obstfeld A, Febbraio M, Kodama T, Silverstein SC (2001) CD11b/CD18 mediates production of reactive oxygen species by mouse and human macrophages adherent to matrixes containing oxidized LDL. Arterioscler Thromb Vasc Biol 21:1301-1305. doi:10.1161/hq0801.095150

122. Kuge Y, Kume N, Ishino S et al (2008) Prominent lectin-like oxidized low density lipoprotein (LDL) receptor-1 (LOX-1) expression in atherosclerotic lesions is associated with tissue factor expression and apoptosis in hypercholesterolemic rabbits. Biol Pharm Bull 31:1475-1482. doi:10.1248/bpb.31.1475

123. Manning-Tobin JJ, Moore KJ, Seimon TA et al (2009) Loss of SR-A and CD36 activity reduces atherosclerotic lesion complexity without abrogating foam cell formation in hyperlipidemic mice. Arterioscler Thromb Vasc Biol 29:19-26. doi: 10.1161/ATVBAHA.108.176644

124. Madan M, Amar S (2008) Toll-like receptor-2 mediates diet and/or pathogen associated atherosclerosis: proteomic findings. PLoS ONE 3:e3204. doi:10.1371/journal.pone.0003204

125. Seimon TA, Obstfeld A, Moore KJ, Golenbock DT, Tabas I (2006) Combinatorial pattern recognition receptor signaling alters the balance of life and death in macrophages. Proc Natl Acad Sci USA 103:19794-19799. doi:10.1073/pnas.060967 1104

126. Freeman-Anderson NE, Pickle TG, Netherland CD et al (2008) Cannabinoid (CB2) receptor deficiency reduces the susceptibility of macrophages to oxidized LDL/oxysterol-induced apoptosis. J Lipid Res 49:2338-2346. doi:10.1194/jlr.M800105JLR200

127. Thorp E, Cui D, Schrijvers DM, Kuriakose G, Tabas I (2008) Mertk receptor mutation reduces efferocytosis efficiency and promotes apoptotic cell accumulation and plaque necrosis in atherosclerotic lesions of apoe-/- mice. Arterioscler Thromb Vasc Biol 28:1421-1428. doi:10.1161/ATVBAHA.108.167197

128. Babaev VR, Chew JD, Ding L et al (2008) Macrophage EP4 deficiency increases apoptosis and suppresses early atherosclerosis. Cell Metab 8:492-501. doi:10.1016/j.cmet.2008.09.005

129. Secchiero P, Candido R, Corallini F et al (2006) Systemic tumor necrosis factor-related apoptosis-inducing ligand delivery shows antiatherosclerotic activity in apolipoprotein E-null diabetic mice. Circulation 114:1522-1530. doi:10.1161/CIRCULATION AHA.106.643841

130. Cappello C, Saugel B, Huth KC et al (2007) Ozonized low density lipoprotein (ozLDL) inhibits NF-kappaB and 
IRAK-1-associated signaling. Arterioscler Thromb Vasc Biol 27:226-232. doi:10.1161/01.ATV.0000250615.27795.85

131. Wang Z, Liu B, Wang P et al (2008) Phospholipase C beta3 deficiency leads to macrophage hypersensitivity to apoptotic induction and reduction of atherosclerosis in mice. J Clin Invest 118:195-204. doi:10.1172/JCI33139

132. Greaves DR, Gordon S (2008) The macrophage scavenger receptor at 30 years of age-current knowledge and future challenges. J Lipid Res [Epub ahead of print]

133. Liang CP, Han S, Okamoto $\mathrm{H}$ et al (2004) Increased CD36 protein as a response to defective insulin signaling in macrophages. J Clin Invest 113:764-773

134. Liang CP, Han S, Senokuchi T, Tall AR (2007) The macrophage at the crossroads of insulin resistance and atherosclerosis. Circ Res 100:1546-1555. doi:10.1161/CIR CRESAHA.107.152165

135. Fernandez-Hernando C, Ackah E, Yu J et al (2007) Loss of Akt1 leads to severe atherosclerosis and occlusive coronary artery disease. Cell Metab 6:446-457. doi:10.1016/j.cmet.2007.10.007

136. Chahine MN, Blackwood DP, Dibrov E, Richard MN, Pierce GN (2009) Oxidized LDL affects smooth muscle cell growth through MAPK-mediated actions on nuclear protein import. J Mol Cell Cardiol 46(3):431-441

137. Cui D, Thorp E, Li Y et al (2007) Pivotal advance: macrophages become resistant to cholesterol-induced death after phagocytosis of apoptotic cells. J Leukoc Biol 82:1040-1050. doi:10.1189/ jlb.0307192

138. Billiet L, Furman C, Cuaz-Perolin C et al (2008) Thioredoxin-1 and its natural inhibitor, vitamin D3 up-regulated protein 1, are differentially regulated by PPARalpha in human macrophages. J Mol Biol 384:564-576. doi:10.1016/j.jmb.2008.09.061

139. Choi JS, Choi YJ, Shin SY et al (2008) Dietary flavonoids differentially reduce oxidized LDL-induced apoptosis in human endothelial cells: role of MAPK- and JAK/STAT-signaling. J Nutr 138:983-990

140. Boullier A, Li Y, Quehenberger O et al (2006) Minimally oxidized LDL offsets the apoptotic effects of extensively oxidized LDL and free cholesterol in macrophages. Arterioscler Thromb Vasc Biol 26:1169-1176. doi:10.1161/01.ATV.0000210279. 97308.9a

141. Schrijvers DM, De Meyer GR, Herman AG, Martinet W (2007) Phagocytosis in atherosclerosis: molecular mechanisms and implications for plaque progression and stability. Cardiovasc Res 73:470-480. doi:10.1016/j.cardiores.2006.09.005

142. Yan ZQ, Hansson GK (2007) Innate immunity, macrophage activation, and atherosclerosis. Immunol Rev 219:187-203. doi: 10.1111/j.1600-065X.2007.00554.X

143. Miller YI, Viriyakosol S, Binder CJ et al (2003) Minimally modified LDL binds to CD14, induces macrophage spreading via TLR4/MD-2, and inhibits phagocytosis of apoptotic cells. J Biol Chem 278:1561-1568. doi:10.1074/jbc.M209634200

144. Ait-Oufella H, Pouresmail V, Simon T et al (2008) Defective mer receptor tyrosine kinase signaling in bone marrow cells promotes apoptotic cell accumulation and accelerates atherosclerosis. Arterioscler Thromb Vasc Biol 28:1429-1431. doi: 10.1161/ATVBAHA.108.169078

145. Tabas I (2007) Apoptosis and efferocytosis in mouse models of atherosclerosis. Curr Drug Targets 8:1288-1296. doi:10.2174/ 138945007783220623

146. Rossing P (2006) Diabetic nephropathy: worldwide epidemic and effects of current treatment on natural history. Curr Diab Rep 6:479-483. doi:10.1007/s11892-006-0083-y

147. Makino H, Kashihara N, Sugiyama H et al (1996) Phenotypic modulation of the mesangium reflected by contractile proteins in diabetes. Diabetes 45:488-495. doi:10.2337/diabetes.45.4.488
148. Verzola D, Gandolfo MT, Ferrario F et al (2007) Apoptosis in the kidneys of patients with type II diabetic nephropathy. Kidney Int 72:1262-1272. doi:10.1038/sj.ki.5002531

149. Ichinose K, Maeshima Y, Yamamoto Y et al (2005) Antiangiogenic endostatin peptide ameliorates renal alterations in the early stage of a type 1 diabetic nephropathy model. Diabetes 54:2891-2903. doi:10.2337/diabetes.54.10.2891

150. Ichinose K, Maeshima Y, Yamamoto $Y$ et al (2006) 2-(8hydroxy-6-methoxy-1-oxo-1 h-2-benzopyran-3-yl) Propionic acid, an inhibitor of angiogenesis, ameliorates renal alterations in obese type 2 diabetic mice. Diabetes 55:1232-1242. doi: $10.2337 / \mathrm{db} 05-1367$

151. Maeda S (2008) Do inflammatory cytokine genes confer susceptibility to diabetic nephropathy? Kidney Int 74:413-415. doi: 10.1038/ki.2008.291

152. Kisseleva T, Brenner DA (2008) Mechanisms of fibrogenesis. Exp Biol Med (Maywood) 233:109-122. doi:10.3181/0707MR-190

153. Boor P, Sebekova K, Ostendorf T, Floege J (2007) Treatment targets in renal fibrosis. Nephrol Dial Transplant 22:3391-3407. doi:10.1093/ndt/gfm393

154. Murphy M, Docherty NG, Griffin B et al (2008) IHG-1 amplifies TGF-beta1 signaling and is increased in renal fibrosis. J Am Soc Nephrol 19:1672-1680. doi:10.1681/ASN.2007101080

155. Schlondorff DO (2008) Overview of factors contributing to the pathophysiology of progressive renal disease. Kidney Int 74:860-866. doi:10.1038/ki.2008.351

156. Ninichuk V, Khandoga AG, Segerer S et al (2007) The role of interstitial macrophages in nephropathy of type 2 diabetic $\mathrm{db} / \mathrm{db}$ mice. Am J Pathol 170:1267-1276. doi:10.2353/ajpath.2007. 060937

157. Usui HK, Shikata K, Sasaki M et al (2007) Macrophage scavenger receptor-a-deficient mice are resistant against diabetic nephropathy through amelioration of microinflammation. Diabetes $56: 363-372$. doi:10.2337/db06-0359

158. Tesch GH (2008) MCP-1/CCL2: a new diagnostic marker and therapeutic target for progressive renal injury in diabetic nephropathy. Am J Physiol Renal Physiol 294:F697-F701. doi: 10.1152/ajprenal.00016.2008

159. Ricardo SD, van Goor H, Eddy AA (2008) Macrophage diversity in renal injury and repair. J Clin Invest 118:3522-3530. doi: 10.1172/JCI36150

160. Wang Y, Wang YP, Zheng G et al (2007) Ex vivo programmed macrophages ameliorate experimental chronic inflammatory renal disease. Kidney Int 72:290-299. doi:10.1038/sj.ki. 5002275

161. Mitchell S, Thomas G, Harvey K et al (2002) Lipoxins, aspirintriggered epi-lipoxins, lipoxin stable analogues, and the resolution of inflammation: stimulation of macrophage phagocytosis of apoptotic neutrophils in vivo. J Am Soc Nephrol 13:24972507. doi:10.1097/01.ASN.0000032417.73640.72

162. Wu SH, Wu XH, Liao PY, Dong L (2007) Signal transduction involved in protective effects of $15(\mathrm{R} / \mathrm{S})$-methyl-lipoxin $\mathrm{A}(4)$ on mesangioproliferative nephritis in rats. Prostaglandins Leukot Essent Fatty Acids 76:173-180. doi:10.1016/j.plefa.2006. 12.006

163. Leonard MO, Hannan K, Burne MJ et al (2002) 15-Epi-16(para-fluorophenoxy)-Lipoxin A(4)-methyl ester, a synthetic analogue of 15-epi-lipoxin A(4), is protective in experimental ischemic acute renal failure. J Am Soc Nephrol 13:1657-1662. doi:10.1097/01.ASN.0000015795.74094.91

164. O’Meara SJ, Rodgers K, Godson C (2008) Lipoxins: update and impact of endogenous pro-resolution lipid mediators. Rev Physiol Biochem Pharmacol 160:47-70. doi:10.1007/112 2006_0606 
165. Moriya R, Manivel JC, Mauer M (2004) Juxtaglomerular apparatus T-cell infiltration affects glomerular structure in Type 1 diabetic patients. Diabetologia 47:82-88. doi:10.1007/ s00125-003-1253-y

166. Fong DS, Aiello L, Gardner TW et al (2003) Diabetic retinopathy. Diabetes Care 26:226-229. doi:10.2337/diacare.26. 1.226

167. The Diabetes Control Complications Trial Research Group (1993) The effect of intensive treatment of diabetes on the development and progression of long-term complications in insulin-dependent diabetes mellitus. N Engl J Med 329:977986. doi:10.1056/NEJM199309303291401

168. UK Prospective Diabetes Study (UKPDS) Group (1998) Effect of intensive blood-glucose control with metformin on complications in overweight patients with type 2 diabetes (UKPDS) 34. Lancet 352:854-865. doi:10.1016/S0140-6736(98)07037-8

169. Piccolino FC, Zingirian M, Mosci C (1987) Classification of proliferative diabetic retinopathy. Graefe's Arch Clin Exp Opthalmol 225:245-250. doi:10.1007/BF02150141

170. Spalter HF (1983) Diabetic maculopathy. Metab Pediatr Syst Ophthalmol 7:211-215

171. Khan ZA, Chakrabarti S (2007) Cellular signaling and potential new treatment targets in diabetic retinopathy. Exp Diabetes Res 2007:31867

172. Kane R, Stevenson L, Godson C, Stitt AW, O'Brien C (2005) Gremlin gene expression in bovine retinal pericytes exposed to elevated glucose. $\mathrm{Br} \mathrm{J}$ Ophthalmol 89:1638-1642. doi: 10.1136/bjo.2005.069591

173. Boado RJ, Pardridge WM (1990) The brain-type glucose transporter mRNA is specifically expressed at the blood-brain barrier. Biochem Biophys Res Commun 166:174-179. doi: 10.1016/0006-291X(90)91927-K

174. Gardner TW, Antonetti DA, Barber AJ, LaNoue KF, Levison SW (2002) Diabetic retinopathy: more than meets the eye. Surv Ophthalmol 47(Suppl 2):S253-S262. doi:10.1016/S00396257(02)00387-9

175. Behl Y, Krothapalli P, Desta T et al (2008) Diabetes-enhanced tumor necrosis factor-alpha production promotes apoptosis and the loss of retinal microvascular cells in type 1 and type 2 models of diabetic retinopathy. Am J Pathol 172:1411-1418. doi:10.2353/ajpath.2008.071070

176. Leal EC, Manivannan A, Hosoya K et al (2007) Inducible nitric oxide synthase isoform is a key mediator of leukostasis and blood-retinal barrier breakdown in diabetic retinopathy. Invest Ophthalmol Vis Sci 48:5257-5265. doi:10.1167/iovs.07-0112

177. Joussen AM, Poulaki V, Qin W et al (2002) Retinal vascular endothelial growth factor induces intercellular adhesion molecule-1 and endothelial nitric oxide synthase expression and initiates early diabetic retinal leukocyte adhesion in vivo. Am J Pathol 160:501-509

178. Early Treatment Diabetic Retinopathy Study Research Group (1991) Effects of aspirin treatment on diabetic retinopathy. ETDRS report number 8. Ophthalmology 98:757-765

179. Boulton AJ, Vinik AI, Arezzo JC et al (2005) Diabetic neuropathies: a statement by the American Diabetes Association. Diabetes Care 28:956-962. doi:10.2337/diacare.28.4.956

180. Tesfaye S, Stevens LK, Stephenson JM et al (1996) Prevalence of diabetic peripheral neuropathy and its relation to glycaemic control and potential risk factors: the EURODIAB IDDM complications study. Diabetologia 39:1377-1384. doi: $10.1007 / \mathrm{s} 001250050586$

181. Figueroa-Romero C, Sadidi M, Feldman EL (2008) Mechanisms of disease: the oxidative stress theory of diabetic neuropathy. Rev Endocr Metab Disord 9:301-314. doi:10.1007/s11154008-9104-2

182. Kabe Y, Ando K, Hirao S, Yoshida M, Handa H (2005) Redox regulation of NF-kappaB activation: distinct redox regulation between the cytoplasm and the nucleus. Antioxid Redox Signal 7:395-403. doi:10.1089/ars.2005.7.395

183. Ha HC, Hester LD, Snyder SH (2002) Poly (ADP-ribose) polymerase- 1 dependence of stress-induced transcription factors and associated gene expression in glia. Proc Natl Acad Sci USA 99:3270-3275. doi:10.1073/pnas.052712399

184. Gruden G, Bruno G, Chaturvedi N et al (2008) Serum heat shock protein 27 and diabetes complications in the EURODIAB prospective complications study: a novel circulating marker for diabetic neuropathy. Diabetes 57:1966-1970. doi:10.2337/ db08-0009 